\title{
Effects of Planting Date and Weeding Regimes on Growth and Yield of Sesame (Sesamum indicum L.) in Sokoto, North- Western Nigeria
}

\author{
H.G. Ahmed, U. Aliyu, A.B. Haruna, Y.S. Isa, and A.S. Muhammad \\ Department of Crop Science, Usmanu Danfodiyo University, Sokoto \\ [Corresponding Author: E-mail-hamidu1970@yahoo.com + 234(0)8022085195]
}

\begin{abstract}
Field experiments were carried out between 2007 and 2008 rainy seasons at the Teaching and Research Dry Land Farm of the Usmanu Danfodiyo University, Sokoto, to investigate the effects of planting date (mid may, early and late June) and weeding regimes (weedy check, weeding once, weeding twice and weed free) on the growth and yield of sesame (Sesamum indicum L.). The experiment was laid out in a Randomised Complete Block Design (RCBD) with three replications. Results obtained indicated that planting date had significant $(\mathrm{P}<0.05)$ influence on plant height, number of branches and number of capsules per plant, seed yield $\mathrm{kg} / \mathrm{ha}$ and weight of 100 seeds. Weeding regime also significantly $(\mathrm{P}<0.05)$ affected plant height, weight of capsules and number of capsules per plant.
\end{abstract}

KEYWORDS: Planting date; Sesame; Seed vield; Weeding regime.

\section{INTRODUCTION}

Sesame (S. indicum) is an annual crop with height ranging from 50 to $100 \mathrm{~cm}$ tall. It is one of the important oil crops and ranked $9^{\text {th }}$ among the top thirteen oil seed crops, which make up to $90 \%$ of the world edible oil production (Kafiriti and Deckers, 2001). The production of high quality seed is prerequisite to successful sesame cultivation. Apart from being the principal method of reproduction, the seed is largely the material from which the edible oil is extracted. The world hectarage exceeds 6 million and world output stood at 2.4 million tonnes (Phillips 1997; Dudley et al., 2000). In Africa, Nigeria is the second largest producer after Sudan. Sesame oil is of good quality. According to Dudley et al. (2000), the oil is used for cooking, baking, candy making, soaps, lubricant, body massage, hair treatment, food manufacture, industrial uses and alternative medicine (blood pressure, stress and tension). Also, Irvine (1970) reported that leaves are used in vegetable soup while seeds are consumed when fried and mixed with sugar in most African countries and stems are used in making paper, fuel wood and source of potash after burning. Sesame has the potential of producing high percent of blossoms, better pod set and pod yield with good agronomic practices (Alam et al., 2007), in which proper weeding and appropriate planting date are inclusive and indispensable. Cane (1949) reported that yield in sesame is progressively reduced with delay in planting from optimum time of sowing. There are few studies conducted as regards to optimum sowing date and weeding regime on the growth and yield of sesame. Field trials were therefore carried out to study the influence of planting date and weeding regime on the growth and yield components in sesame.

\section{MATERIALS AND METHODS}

Field trials were conducted at the Teaching and Research Dry land farm of the Usmanu Danfodiyo University, Sokoto (latitude $13^{\circ}$ $01^{\prime} \mathrm{N}$ and $5,^{\circ} 15^{\prime} \mathrm{E}$ ) during the 2007 and 2008 rainy seasons. The soil of the site is sandy and characterize by low fertility and poor water holding capacity. The annual rainfall range from $500 \mathrm{~mm}$ to $750 \mathrm{~mm}$ and the temperature range from $17^{\circ} \mathrm{C}$ in December and January to a maximum of $40^{\circ} \mathrm{C}$ in April and May.

The treatments consisted of three planting dates (mid May, early June and late June) and four weeding regimes (weedy check, weeding once, weeding twice and weed free) arranged in all possible factorial combinations and laid out in a randomized complete block design with three replications. The land was harrowed and a blanket dose of $30 \mathrm{kgN}, 30 \mathrm{kgP}_{2} 05$ and $30 \mathrm{kgK}_{2} 0$ per hectare (using 15:15:15 NPK) was applied after first weeding. $\mathrm{N}$ was splited in two doses with second dose applied six weeks after planting. The plots were weeded as per treatments and appropriate pests and diseases control were carried out.

Data were collected on establishment count, plant height, weed cover score, weed dry weight, number of branches per plant, number 
of capsules per plant, capsule, seed yield and weight of 100 seeds. Data on growth and yield components were analysed as described by Snedecor and Cochran (1967). Multiple comparisons of treatment means were done using Duncan's multiple Range Test (Carmer and Swanson, 1973).

\section{RESULTS AND DISCUSSION Establishment count}

Planting date and weeding regime had no significant $\quad(\mathrm{P}>0.05)$ effect on stand establishment count in both seasons (Tables $1 \& 2$ ). This could be as a result of proper land preparation and use of quality seeds. Use of quality seeds coupled with good land preparation give an excellent establishment in sesame (Cane, 1949).

\section{Plant height}

Plant height was significantly $(\mathrm{P}<0.05)$ affected by planting date (Table 1). Mid May planting had significantly $(\mathrm{P}<0.05)$ produced the tallest plants than early June and late June plantings. Early June planting and late June planting were statistically at par. Mid May planting had enough time to grow vegetatively than early and late June plantings which might likely be the reason for producing tallest plants. Similar results were reported by Van-Rheenan (1973), Mulkey et al. (1987), Kafiriti and Deckers (2001) and Alam et al. (2007) on the effect of planting date on sesame plant height.

Table1. Effect of Planting Date on Growth and Yield Parameters of Sesame During 2006/2007 and 2007/2008 Rainy Seasons at Usmanu Danfodiyo University Teaching and Research Dry Land Farm, Sokoto

\begin{tabular}{lccccc}
\hline Parameters & Mid May & Early June & Late June & SE+ & Significant \\
\hline Establishment count & 49.33 & 51.53 & 51.56 & 1.18 & $\mathrm{~ns}$ \\
Plant height $(\mathrm{cm})$ & $152.89 \mathrm{a}$ & $148.91 \mathrm{~b}$ & $135.93 \mathrm{~b}$ & 4.43 & $* *$ \\
No. of branches per plant & $4.77 \mathrm{a}$ & $4.69 \mathrm{a}$ & $3.16 \mathrm{~b}$ & 0.19 & $* *$ \\
No. of capsules per plant & $81.90 \mathrm{a}$ & $67.12 \mathrm{a}$ & $55.44 \mathrm{~b}$ & 4.12 & $* *$ \\
No. of seeds per capsule & 50.08 & 47.75 & 48.58 & 0.77 & $\mathrm{~ns}$ \\
Weight of 100 seeds & $0.39 \mathrm{a}$ & $0.35 \mathrm{a}$ & $0.29 \mathrm{~b}$ & 0.05 & $* *$ \\
Seed yield (Kg/ha) & $1102.66 \mathrm{a}$ & $1057.73 \mathrm{a}$ & $758.22 \mathrm{~b}$ & 282.32 & $* *$ \\
Weed cover score & 52.50 & 50.83 & 48.33 & 10.29 & $\mathrm{~ns}$ \\
Weed dry weight $(\mathrm{g})$ & 473.6 & 479.6 & 480.8 & 125 & $\mathrm{~ns}$ \\
\hline
\end{tabular}

Means in a row of treatments followed by different alphabet(s) are significantly different at 5\% significant level using Duncan Multiple Range Test (DMRT). ns= not significant

Table2. Effect of Weeding Regime on Growth and Yield Parameters of Sesame During 2006/2007 And 2007/2008 Rainy Seasons at Usmanu Danfodiyo University Teaching and Research Dry Land Farm, Sokoto

\begin{tabular}{lllllll}
\hline Parameters & $\begin{array}{l}\text { Weedy } \\
\text { check }\end{array}$ & $\begin{array}{l}\text { Weeding } \\
\text { once }\end{array}$ & $\begin{array}{l}\text { Weeding } \\
\text { Twice }\end{array}$ & $\begin{array}{l}\text { Weed } \\
\text { free }\end{array}$ & SE+ & $\begin{array}{l}\text { Significanc } \\
\text { e }\end{array}$ \\
\hline Establishment count & 49.22 & 51.55 & 49.88 & 53.11 & 1.02 & $\mathrm{~ns}$ \\
Plant height $(\mathrm{cm})$ & $129.80 \mathrm{c}$ & $155.31 \mathrm{a}$ & $143.47 \mathrm{~b}$ & $155.10 \mathrm{a}$ & 3.66 & $* *$ \\
No. of branches per plant & $3.31 \mathrm{~b}$ & $3.99 \mathrm{a}$ & $3.95 \mathrm{a}$ & $5.58 \mathrm{a}$ & 0.16 & $* *$ \\
No. of capsules per plant & 43.55 & 46.88 & 50.66 & 54.11 & 0.66 & $\mathrm{~ns}$ \\
No. of seeds per capsule & 43.55 & 46.88 & 50.66 & 54.11 & 0.66 & $\mathrm{~ns}$ \\
Weight of 100 seeds & 0.35 & 0.34 & 0.35 & 0.35 & 0.06 & $\mathrm{~ns}$ \\
Seed yield (Kg/ha) & 784.10 & 995.07 & 992.85 & 1249.20 & 323.23 & $\mathrm{~ns}$ \\
Weed cover score & $72.32 \mathrm{a}$ & $36.69 \mathrm{~b}$ & $21.33 \mathrm{~b}$ & 00.00 & 35.39 & $* *$ \\
Weed dry weight $(\mathrm{g})$ & $874.8 \mathrm{a}$ & $466.4 \mathrm{~b}$ & $426.4 \mathrm{~b}$ & 00.00 & 144.4 & $* *$ \\
\hline
\end{tabular}

Means in a row of treatments followed by different alphabet(s) are significantly different at 5\% significant level using Duncan Multiple Range Test (DMRT). ns= not significant

Weeding regime also had significant effect on plant height (Table 2). Effect of weeding once and weed free were statistically the same and differed significantly from weedy check and weeding twice. Weedy check produced significantly shortest plants than the rest of the weeding regimes mainly due to competition from weeds. This result is in conformity with that of Lagoke (1978) who reported that weeds 
had detrimental effect on growth and development of crops.

\section{Number of branches per plant}

The mid May and early June plantings had produced the same number of branches but produced significantly more number of branches than late June planting (Table 1). Number of branches decreased from mid May to late June. Delay in planting decreases the number of branches per plant (Tilak at al. ,1971; Alam at al., 2007). They maintained that the fewer number of branches in delayed planting may be as a result of environmental factors more, importantly the rainfall. Weed free treatment produced significantly $(\mathrm{p}<0.05)$ higher number of branches per plant than weedy check and weeding once and twice (Table 2). Weedy check had the lowest number of branches per plant than the rest of the treatments and could be due to excessive competition for soil nutrients and space between the target crop and the weeds. The result is in conformity with what was reported by Deckers (2001) that in the persistent presence of weeds, number of branches per plant decreases due to competition. The effect of interaction of planting date and weeding regime shows significant difference on the number of branches per plant (Table 3). The highest number of branches per plant was obtained when sesame was planted in mid May and kept weed free while the lowest number of branches per plant was obtained at the late June planting and when the plots were not weeded.

\section{Number of capsules per plant}

Planting date had significant effect on the number of capsules per plant (Table 1). Mid May planting had significantly $(\mathrm{P}<0.05)$ more number of capsules per plant than both early June and late June plantings which were found to be at par. Number of capsules decreased consistently with delay in planting date. This result was in line with that of Alam et al. (2007) who reported that delay in planting decreased the number of capsules produced. Weed free had significantly $(\mathrm{P}<0.05)$ higher number of capsules per plant than the rest of the weeding regimes. Weeding once and weeding twice were statistically at par while weedy check had significantly ( $\mathrm{P}>0.05)$ lower number of capsules per plant. Dowson (1970) reported that most of the reduction in crop vigour and yield was as a result of weed competition with crops for essential nutrients, water below the soil and for light and space above the soil surface.

Interaction effect of planting date and weeding regime was significant on the number of capsules per plant (Table 3). The best combination was that of mid May planting and weed-free plots. This was as a result of availability of soil moisture coupled with the absence of weeds competition which enabled the target crop to effectively utilize soil nutrients, moisture and probably light and space during both vegetative and reproductive stages. Yayock et al. (1988) reported that as a consequence of large scale problem posed by weeds, more than half of the cultural practices required for better crop growth and yield are devoted to the control of weeds.

\section{Seed yield (kg/ha)}

Mid May planting and early June planting were similar statistically and differed significantly $(\mathrm{P}<0.05)$ from late June planting (Table 1). Seed yield decreased as the planting date was delayed from mid May to late June. Ashtana and Narain (1977), Rahman et al. (1994) and Alam et al. (2007) also reported that highest seed yields were obtained from the early sown Sesame compared to the late sown ones. The higher seed yield obtained from the early sown Sesame was mainly due to the production of higher number of branches and capsules per plant. Weeding regimes have no significant effect of on the seed yield of sesame.

\section{0 seeds weight $(\mathrm{g})$}

Planting date has significant effect on the weight of 100 seeds. The highest value was obtained from mid May planting which was statistically at par with what was obtained from early June planting. Alam et al. (2007) have also reported significant effect of planting date on the weight of 1000 seeds of sesame. Weeding regime has no significant effect on the weight of 100 seeds weight of sesame. This is in conformity with the report of Zimdahl (1985) who stated that final yield was unaffected by initial weed competition.

\section{Weed cover score $(\%)$ and weed dry weight (Kg/ha)}

Planting date had no significant effect $(\mathrm{P}>0.05)$ on both weed cover score and weed dry weight (Tables 1\&2). However, weeding regime had significant effect $(\mathrm{P}<0.05)$ on weed cover score and weed dry weight. Weedy check was the 
highest for both parameters and differed significantly from the rest of the weeding regimes. These observations are generally obvious in the sense that weedy check received no weeding throughout the period of the experimentation and therefore likely to have more weed cover score and weed dry weight than the rest of the weeding regimes. This is in conformity with what was reported by Yayock et al. (1988).

Table 3: Effect of Interaction Between Planting Date and Weeding Regimes on the Growth and Yield Parameters of Sesame During 2006/2007 Rainy Season at Usmanu Danfodiyo University Dry Land Farm, Sokoto.

\begin{tabular}{cccc}
\hline $\begin{array}{c}\text { Planting date } x \\
\text { Weeding regime }\end{array}$ & $\begin{array}{c}\text { Number of branches per } \\
\text { plant }\end{array}$ & $\begin{array}{c}\text { Number of capsules } \\
\text { per plant }\end{array}$ & Weed cover score (\%) \\
\hline P1WO & $3.65 \mathrm{f}$ & $64.48 \mathrm{~d}$ & 100.00 \\
P1W1 & $4.09 \mathrm{e}$ & $76.36 \mathrm{c}$ & 76.66 \\
P1W2 & $4.99 \mathrm{c}$ & $83.72 \mathrm{~b}$ & 33.33 \\
P1WF & $6.35 \mathrm{a}$ & $102.48 \mathrm{a}$ & 0.00 \\
P2WO & $3.60 \mathrm{f}$ & $36.63 \mathrm{~g}$ & 73.33 \\
P2W1 & $4.92 \mathrm{c}$ & $76.36 \mathrm{c}$ & 66.66 \\
P2W2 & $4.27 \mathrm{de}$ & $70.03 \mathrm{c}$ & 63.33 \\
P2WF & $5.99 \mathrm{~b}$ & $85.22 \mathrm{~b}$ & 0.00 \\
P3WO & $2.69 \mathrm{~h}$ & $43.95 \mathrm{f}$ & 100.00 \\
P3W1 & $2.98 \mathrm{~g}$ & $40.62 \mathrm{f}$ & 53.33 \\
P3W2 & $2.59 \mathrm{~h}$ & $54.36 \mathrm{e}$ & 40.00 \\
P3WF & $4.39 \mathrm{~d}$ & $82.84 \mathrm{~b}$ & 0.00 \\
SE+ & 0.03 & 8.10 & \\
\hline
\end{tabular}

Means in a column of treatments followed by different alphabet(s) in superscript(s) are significantly different at 5\% significant level using Duncan Multiple Range Test (DMRT). P1=Mid May planting, P2=Early June, P3=Late June, Wo=Weedy check, W1=Weeding once, W2=Weeding twice, W3=Weedy free.

\section{REFRENCES}

Alam S.M.N., M. Salim, N. Islam and M.M. Rahman (2007). Effect of sowing date and time of harvesting on the yield and yield contributing characters of sesame (Sesame indicum L) seed. Int. J. Sustain. Crop Prod. 2(6): 31-35

Ashnata,K.S, B. Narain (1977). Evaluation of sesame varieties in Bihar for summer. Indian J. Agric. Sci. 47(12): 611-613.

Cane, J. (1949). Preliminary studies on sesame in Salvador, Central America. Proc. $1^{\text {st }}$ Inter. Sesame Conf. Clemson Agric. Coll., USA. Pp232-236

Dowson, J.A. (1970). Time and Direction of weed infestation, Proc. $3^{\text {rd }}-5^{\text {th }}$ weed control conf. Pp 13-35.

Dudley, T.S., W. James and A. Mc callum(2000). Texas Agricultural Experimental Station, College Station and Yankum. Prepared April 12, 2000. P125

Irvine J. (1970). West African Crops $3^{\text {rd }}$ edition, Oxford University Press, Pp 71-74.

Kafiriti E.M. and J. Deckers (2001). Sesame in: Raemnekers, Rlt (ed.) Crop Production in
Tropical Africa DGIC, Brussels, Belgium, P345

Lagoke, S.T.O. (1978). Method of control of spear grass (Imperata cylindrica Beaur) In Maize (Zea mays L) PhD Thesis, University of Ibadan, Nigeria, P410. (unpublished)

Martin, E.M. and H. John (1991). Principles of field crops production. Pearson Prentice Hall, New Jersey, Pp 137-140.

Mulkey, J.R., H.J. Drawe and R.E.J.R. Elledge (1987). Planting date effects on plant growth and development in sesame. Agron. J. 79 (4): 701-70.

Phillips, T.A. (1997). Agricultural Note Book Series, Longman publishers, London. Pp 61-62.

Rahman, M.M., M.G. Maula, S. Begun and M.A. Hossain (1994). Maximization of yield of sesame through management practices, Central Annual Research. BARI, Joydebpor, Gozipur. pp 53-56.

Tilak, R., B.M.Sharma, P. Mahabir (1971). Effect of sowing date, nitrogen levels and spacings on the performance of rainfed 
sesame (Sesame indicum $L$ ). Indian $J$. Agron. 16(2): 252-254.

van-Rheenan, H.A. (1973). Major problems of growing sesame in Nigeria. $\mathrm{PhD}$. Thesis Universityof Wageningen. (unpublished)
Yayock, J.Y., Lombin, G., Owonubi, J.J. and C.O. Onazi (1988). Crop Science and Production in Warm Climate. Publishers, Macmillan Ltd. London and Basingstoke. 